\title{
Financial Viability of a Photovoltaic System: the case of University Hospital at the UFSCar/Brazil
}

Versão do autor aceita publicada online: 06 dez. 2021

Publicado online: 06 jan. 2022

Como citar esse artigo - American Psychological Association (APA): Duaik, I. R., Ferraz, D., Silveira, N. J. C., Torres, C. E. da G., \& Rebelatto, D. A. do N. (2022). Financial Viability of a Photovoltaic System: the case of University Hospital at the UFSCar/Brazil. Exacta. DOI: https://doi.org/10.5585/exactaep.2022.20292.

\section{Isis Restivo Duaik}

Universidade de São Paulo

Engenheira. Departamento de Engenheira Elétrica da Escola de Engenharia de São Carlos (EESC) Universidade de São Paulo (USP).

\section{Diogo Ferraz}

https://orcid.org/0000-0003-4037-7171

https://www.researchgate.net/profile/Diogo_Ferraz

Universidade Federal de Ouro Preto

Universidade Estadual Paulista

University of Hohenheim (Stuttgart/Germany)

Doutor em Engenharia de Produção na Universidade de São Paulo(USP). Ph.D. candidate em Economia na Universität Hohenheim (Departamento de Economia - Economia da Inovação, Stuttgart/Alemanha). Economista. Professor Permanente do Programa de Pós-Graduação em Engenharia de Produção da UNESP-Bauru e do Programa de Pós-Graduação em Economia Aplicada (PPEA) da Universidade Federal de Ouro Preto (UFOP).

\section{Naijela Janaina Costa Silveira}

https://orcid.org/0000-0003-1398-2384

Universidade Federal de São Carlos

Universidade Paulistâ

Professora de Engenharia de Produção e Engenharia de Produção Mecânica da Universidade Paulista (UNIP). Doutora em Engenharia de Produção pela Universidade Federal de São Carlos - UFSCar. Atuou na linha de pesquisa de Gestão de Tecnologia e Inovação por meio de ferramentas econométricas e Análise Envoltória de Dados. Póssui ênfase em análise de dados em painel e regressão por limiar. Possui Mestrado em Engenharia de Produção pela Universidade Federal de São Carlos e graduação em Engenharia de Produção pela Universidade Estadual do Paraná.

\section{Carlos Eduardo da Gama Torres}

Universidade Federal de Ouro Preto

Possui graduação em Ciências Econômicas pela Universidade Federal de Minas Gerais (1992), mestrado em Economía pela Universidade Federal do Rio Grande do Sul (1999) e doutorado em economia no Cedeplar-UFMG (2009). É professor do curso de graduação em Ciências Econômicas e do curso Pós Graduação em Economia Aplicada da na Universidade Federal de Ouro Preto . Tem experiência na área de Economia, atuando principalmente nos seguintes temas: infra-estrutura, desenvolvimento regional e transportes.

\section{Daisy Aparecida do Nascimento Rebelatto}

https://orcid.org/0000-0003-0611-1492

Universidade de São Paulo

Possui graduação em Engenharia Civil pela Universidade Federal de São Carlos (1984), mestrado em Engenharia de Produção pela Universidade de São Paulo (1992), doutorado em Engenharia Mecânica 
pela Universidade de São Paulo (1999), pós-doutorado pela Universidad Complutense de Madrid (2004) e pela Universidad de Salamanca (2008), livre-docência pela Universidade de São Paulo (2005). Atualmente é professor associado da Universidade de São Paulo, membro do corpo editorial dos periódicos: - Revista de Engenharia e Ciências Aplicadas , - Produção (São Paulo) (0103-6513), Revista Produção Online, - RAP. Revista Brasileira de Administração Pública e - Gestão e Produção (UFSCar). Tem experiência na área de Engenharia de Produção, com ênfase em Engenharia Econômica, atuando principalmente nos seguintes temas: análise de investimento, competitividade, inovação tecnológica, sustentabilidade, capital privado e capital público.

Abstract: Considering the negative consequences of the excessive use of non-renewable energy and the development of technologies related to photovoltaic energy, the present paper aims to analyze if the photovoltaic systems are economically viable for university hospitals. A photovoltaic system was designed in the parking lot of the University Hospital of the Federal University of São Carlos (UFSCar) and analyzed the financial viability of its installation. As a result, the photovoltaic system is financially viable, with an expected generation of 194.2 MWh in the first year and a payback of 7 years. Thus, this paper contributes to the feasibility of photovoltaic projects in university hospitals, reducing electric energy consumption, reducing its operational costs, reducing the emission of pollution, and diversification of the Brazilian energy matrix. Furthermore, the results can be used as a scientific basis for other fields, such as public and private hospitals and clinics.

Keywords: Renewable. Energy. Photovoltaic system. Hospitals.

\section{Introduction}

Excessive use of non-renewable energy resources results in a negative environmental impact, in addition to the depletion of their reserves, leading, for example, to worsening global warming, acid rain, emission of pollutants into the atmosphere, storage of radioactive waste, accidents with nuclear power plants and contamination of water (Villalva, 2015). In this sense, modern society encourages low-carbon energy sources to generate economic growth without damaging the environment. It could occur by increasing the participation of renewable resources in the economic development process (Chien et al., 2021).

According to the Energy Research Company (2017), in 1980, the world's energy generation through fossil fuels represented $70 \%$ and in 2014 represented 66\%. In other terms, this source still has a high representation in the world energy matrix. In contrast, the United States of America (USA) decreased coal-based electricity production to use more renewable resources during economic growth (IEA, 2020). However, Nathaniel and Iheonu (2019) pointed 


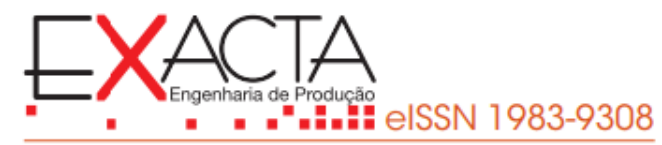

out that several developed countries might keep damaging the environment, which causes more issues to developing nations. Considering the eventual depletion of these non-renewable sources and the damages generated through their use, the current world energy matrix can be considered unsustainable in the long term. In this scenario, there are different movements for a more sustainable future. For example, one of the United Nations' 2030 Agenda for Sustainable Development goals is to "Ensure Sustainable Production and Consumption Standards" (United Nations, 2015; Hartmann et al., 2021). It is intended, by 2030, to achieve sustainable management and efficient use of natural resources (Tsalis et al., 2020; Adenle, 2020).

Renewable sources of energy are considered to be inexhaustible according to human usage patterns. They come from natural Earth cycles such as solar radiation and winds (Nazir et al., 2020). Some renewable sources are hydro, wind, geothermal, biomass, and solar energy (Villalva, 2015). Space once conquered by fossil sources is being conquered by these [renewable] energies through technological development, which allows them to be better utilized.

As observed by Pergher (2011), in the search for renewable sources, Brazil presents a significant differential concerning other countries because its biodiversity allows the generation of energy through various means, including hydroelectric, solar, and wind, besides the development of alternative sources such as the use of biomass, used for the production of renewable fuels, such as ethanol, biodiesel, among others (Agronegócios and Tecnologias, 2006; Fraundorfer and Rabitz, 2020). According to the Balanço Energético Nacional do Ministério de Minas e Energia (MME), Brazil emerges as a leader in renewable energy. In 2016, more than $70 \%$ of the electricity generation in Brazil originated from renewable sources.

Among the renewable sources, there is photovoltaic solar energy. Sidawi (2011) observed that solar energy comes from the photovoltaic effect that directly transforms light into electrical energy through solar cells, producing electricity. The benefits of this source are numerous, varying from the non-emission of pollutants such as $\mathrm{NOx}, \mathrm{SO}_{2}, \mathrm{CO}$, and greenhouse gases $\left(\mathrm{CO}_{2}, \mathrm{CH}_{4}, \mathrm{~N}_{2} \mathrm{O}\right.$, and others) to reducing electricity costs (EPE, 2017).

Brazil has more than $1 \mathrm{GW}$ of installed capacity in solar power plants. In a note, the Brazilian Association of Photovoltaic Solar Energy announced that this level was reached by only 30 countries in the world (ABSOLAR, 2018). Furthermore, in 2014 and 2015, ANEEL conducted auctions for the contracting of energy from new photovoltaic projects, resulting in new solar plants in the country (ANEEL, 2015).

In addition to expanding power plants, another growth front is distributed generation: the consumer generating its electricity from renewable sources. With the development and 


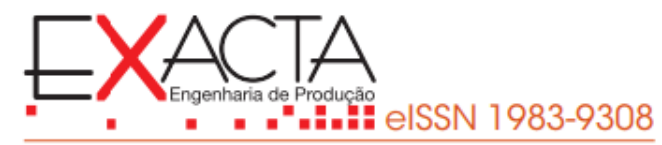

popularization of technologies related to distributed generation, consumers have evolved from a passive position to act in the electric sector (MME / EPE, 2017) and can generate their energy. As a result, in 2016, there was a more than fourfold increase in the number of plants with distributed generation. Most of the generation is concentrated in the Southeast, mainly in São Paulo and Minas Gerais (ANEEL, 2017).

The incentives to distributed generation are justified by the potential benefits such modality can provide to the electric and consumers. These include the postponement of investments in the expansion of transmission and distribution systems, low environmental impact, reduction in network loading, minimization of losses, diversification of the energy matrix (ANEEL, 2015), cost minimization, and ease installation. In addition, this ease of installation generates opportunities for technology implementation in residential, public, commercial, cultural, and sports buildings; landfills; Street lighting, among others, creating opportunities to use spaces that are often underutilized (EPE, 2017).

Hospitals are among those with greater electric energy consumption among the public buildings due to the many electrical and electronic equipment used for patient care. Also used are boilers for water heating and steam production, often fueled with fossil fuels that cause significant environmental impact. With this, photovoltaic technology in hospitals shows a relevant theme (Rocha, 2012).

In this way, this article contributes to the feasibility of photovoltaic projects in University Hospitals - UH, aiming to reduce the consumption of electric energy in this type of public buildings, eventually leading to a decrease in its operational costs, reduction of pollution, and diversification of the Brazilian energy matrix. In addition, the results of this paper may be used as a scientific basis for other studies, such as hospitals and clinics, both public and private.

Therefore, the following research question is asked: Are photovoltaic systems financially viable for university hospitals? To answer this question, this paper aims to analyze the financial viability of installing a photovoltaic system in the University Hospital of UFSCar. This article develops a bibliographical review on Photovoltaic Energy, describes the method and analyzes the project's cash flow and the financial viability of photovoltaic projects in a university hospital.

This paper contributes to the feasibility of photovoltaic projects in university hospitals, which can reduce the electric energy consumption in the establishment, leading to the reduction of its operational costs, reduction of the emission of pollution, and diversification of the Brazilian energy matrix. In addition, the results of this work may be used as a scientific basis for other studies, such as hospitals and clinics, both public and private. 


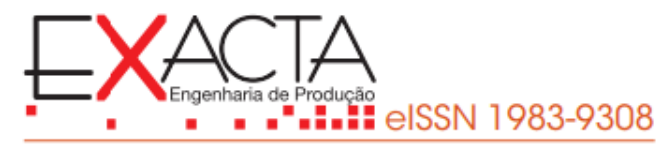

The present paper is organized into four sections besides this introduction. The second section presents the literature review on renewable energy and photovoltaic energy. The third section describes the research method and presents brief information on the case study. The fourth section presents our findings. Finally, the fifth section describes our conclusion.

\section{Photovoltaic Energy}

The current world energy matrix is proving unsustainable because it depends mainly on non-renewable sources. Since 1997, with the signature of the Kyoto protocol, there has been a more significant concern with the reduction of energy from sources that generate waste to the planet (Nathaniel and Iheonu, 2019). In this way, renewable sources such as solar photovoltaic, wind, hydroelectric, and biomass have gained more space in the world energy matrix (Nazir et al., 2020).

At the same time, society has been undergoing a drastic change in the energy-generating agent. Before, consumers were only passive agents, consuming the energy coming from the electric power grid, the consumer is now taking a more active role in energy generation (Tsalis et al., 2020; Adenle, 2020). Even though it is timid, there have been decentralized electricity production plants since people and entities can produce their energy with photovoltaic solar energy. Besides increasing the consumption of a renewable source, this own production also gives greater financial independence to its users, who start to spend less with electricity, allowing the investment of this money in other activities (Chien et al., 2021).

Given this context, it is essential to note that there are different movements for sustainability. One of the objectives of the Agenda 2030 for Sustainable Development is "to ensure sustainable production and consumption patterns". It is expected that, by 2030, it will be possible to make all management sustainable and efficient use of natural resources. In this scenario, countries such as Brazil, rich in renewable sources, stand out, which presents a favorable condition for the transition of the energy matrix. In this sense, it is essential to develop projects that prove the technical and economic feasibility of implementing clean and renewable energy sources systems for this to happen. According to Moralles e Rebelatto (2016), government investment in innovation plays a vital role in companies.

Several studies debate the impact of electricity generation on greenhouse gas emissions and $\mathrm{CO}_{2}$ emissions (Charfeddine and Kahia, 2019). For this reason, the top world renewable energy investors (China, India, and the United States of America) have given more importance to renewable resources, such as wind and solar energy, to avoid environmental damage in developed and developing countries (REN21, 2020; Xia and Wang, 2020). According to 


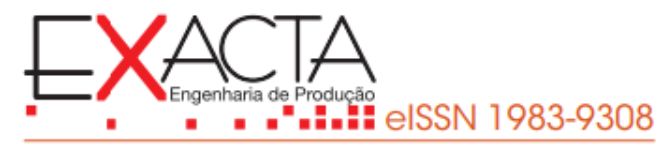

Rehman et al. (2020), the investment in renewable energy (i.e., solar photovoltaic) is an adequate strategy to provide economic growth through a more diverse energy matrix. In fact, China is investing in renewable energy, such as photovoltaic generation, which increased from 22 GWh in 2000 to 130,658 GWh in 2018 (Xu et al., 2020). The same occurs with India, which increased the photovoltaic capacity and other renewable resources from 6,583 (ktoe) in 2000 to 19,662 (ktoe) (Vidyarthi and Mishra, 2020).

The photovoltaic principle was discovered by the French physicist Alexandre-Edmond Becquerel in 1839 (Becquerel, 1839). However, the photovoltaic effect was best known when, in 1887, Heinrich Hertz showed that the charge induced by light could lead to an electric current (Hertz, 1887), which became known as the photovoltaic effect. The photovoltaic effect is the physical phenomenon that makes the direct conversion of light into electricity. The photovoltaic cell is the fundamental unit of this conversion process (Pinho and Galdino, 2014).

The isolated systems are autonomous photovoltaic systems characterized by not being connected to the public electricity grid. They serve remote locations such as rural areas, islands, isolated communities, or anywhere else that does not reach electric power. This system is also used as a solution in cases with no energy, such as refrigerators to store vaccines, water pumping, electrification of fences, and signal replicating stations. In many cases, isolated photovoltaic systems are the best option because they require little maintenance, are quiet, and are ecologically correct (Villalva, 2015).

In this configuration, during the day, the panels generate electricity and charge the system batteries. The battery, or bank of materials, serves to store the energy produced by the system. In this way, energy consumption does not necessarily have to coincide with energy production. It is possible to use the energy produced even on cloudy, rainy, or even night days (Villalva, 2015).

Connected systems operate in parallel with the power grid and aim to reduce or eliminate the consumption of the public grid or even generate surplus energy. There are three different categories for on-grid systems: power plants and distributed generation microgeneration and mini-generation.

Photovoltaic systems connected to the grid with installed power up to 100 kilowatts $(\mathrm{kW})$ are called microgeneration, and systems with installed power between $100 \mathrm{~kW}$ and $1 \mathrm{MW}$ are called minigeration (Villalva, 2015).

Over the past few years, several government programs have been promoting the increased use of photovoltaic solar energy in Brazil. In 2011, the National Electric Energy Agency (ANEEL) launched the strategic project - "Technical and Commercial Arrangements 


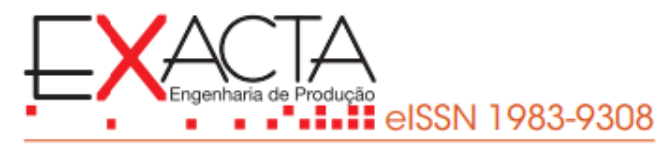

for the Insertion of Solar Photovoltaic Generation in the Brazilian Energy Matrix" (ANEEL, 2011). In 2012, ANEEL issued Normative Resolution No. 482, creating conditions for accessing micro and mini-energy to electricity. The consumer was able to generate his electricity from renewable sources or qualified cogeneration and even provide the surplus to the distribution network, also called distributed production (ANEEL, 2016).

As of October 2017, there were 16,000 micro-generation and mini-generation systems operating in Brazil and more than 81 million consumer units in Brazil. That is, distributed solar photovoltaic generation accounted for only $0.02 \%$ of the consuming units in the country (Sauaia, 2017).

The amount of energy produced through a photovoltaic solar energy system is dependent on the climatic and atmospheric conditions of the place where it is installed. Of the radiation coming from the Sun, only part of it reaches the Earth's surface due to the reflection and absorption of the sun's rays through the atmosphere. According to CRESESB - Reference Center for Solar and Wind Energy Sergio de S. Brito, solar energy on the earth's surface is about 10,000 times the world energy consumption (CRESESB, 2008).

Comparing Brazil with other countries that use photovoltaic solar energy, Brazil has a higher index of average insolation. For example, Germany is the country that uses the most solar photovoltaic energy, with most of the territory receiving less than 3500 watt-hours per square meter $(\mathrm{Wh} / \mathrm{m} 2)$ daily of solar energy. At the same time, Brazil presents values of daily sunshine between $4500 \mathrm{Wh} / \mathrm{m} 2$ and $6000 \mathrm{Wh} / \mathrm{m} 2$.

According to Villalva (2015), it is considered reasonable to expect a potential of photovoltaic generation, at least ten times higher than the installed capacity in Germany, due to the territorial dimensions and the high rates of solar irradiation. Thus, it is considered that there is a lot of room for the growth of photovoltaic solar energy in the country, to the point of becoming a relevant part of the Brazilian energy matrix.

Although there are already financing programs for high-cost projects such as BNDES (BNDES, 2009), economic incentives such as subsidies or credit lines for small and mediumsized photovoltaic systems are still incipient. Seeking to change this scenario, in June 2018, the National Bank for Economic and Social Development (BNDES) approved changes that will allow individuals to access financing for the installation of solar heating systems and cogeneration systems, with photovoltaic panels and wind turbines (Barbosa, 2018).

Considering Brazil with full utilization of its photovoltaic solar energy capacity is a highly optimistic scenario. In this scenario, energy would have an extremely competitive price, reduce the price of the consumer's energy bill, bring environmental benefits, boost 
technological development in the country, create jobs in the development and the installation, maintenance, and service sectors, beyond the moving the national economy. A significant investment is needed to build a conventional plant. In the distributed generation scenario, this investment would be pulverized in several smaller investments, thus instigating the country's economy.

\section{Method}

The first step in defining the implementation site was visiting UH-UFSCar with those in charge of the hospital. During the visit were possible locations that will be analyzed, discussed, and prioritized throughout this paper. To decide the best place for the development of the project, criteria such as total area, shading, terrain slope, and the possibility of future construction that impacted the chosen site were taken into account.

Initially, the three possible locations were measured, and then the area available for implementing the photovoltaic system in each of the options was calculated. Then photos and videos were taken at different times of the same day to study the shadowing caused by buildings and nearby vegetation, which is a reason to make the site unsuitable for installing a photovoltaic system. As studied in the bibliographic review chapter, the cells of a photovoltaic module are connected in series, depending on each other to produce current. When all cells receive the same amount of light, the electric current flows typically through the terminals of the module. However, if any cells are shaded, the electric current will be impeded in this cell, causing the photovoltaic module to stop producing energy in the rest of the set.

Another relevant factor to be considered for decision making is the unevenness of the terrain of these areas, as this directly impacts the required structure, i.e. a terrain with a considerable slope would need a high structure cost, which makes the payback of the longer project, and may even make it unfeasible.

The last aspect considered was the possibility of future constructions around the sites since some works of UH-UFSCar have not yet been finalized. This directly impacts the project since the construction of new buildings can generate shading of the site, making it unfeasible.

With the data collected, it was possible to choose the best place to install the system. The most relevant items for the decision-making were the area and the shadowing of the sites. After deciding where to install the photovoltaic system, its physical limitations were analyzed to know how much energy could be generated through this site. These analyses were made from the PVsyst program, simulation software for photovoltaic systems. 
The software considers factors such as the solar incidence of the area, the area allows the choice of different models of panels and inverters, and the choice of the slope of the panels. To achieve feasible results, the software also considers the different types of losses such as loss by shading, ohms, and decreasing the efficiency of the set according to the increase in the lifetime. The first data to be entered in the software is the type of system connection: system connected to the network or isolated system. In this paper, a photovoltaic system connected to the grid is being studied.

Next, the latitude and longitude data of the chosen location are inserted so that the software can take into account the solar incidence of the region. This data was imported from the database contained in it. The sequence determined the inclination with which the panels would be installed in the available area and, by choosing the components to be used, the system could be dimensioned.

After the system's technical design in the chosen location, the need for a total investment of the work was raised. That is, the different costs involved were calculated. To calculate the cost of the scaled system, several quotations were made with different suppliers of photovoltaic equipment to find the materials that had the best cost-benefit according to the system's needs. This part of the paper quoted the prices of panels, inverters, protection devices, and the structure necessary to support the assembly. In addition to the cost of materials, labor costs were also raised for the system's installation in the chosen location and the maintenance cost during the 25-year duration of the system.

From the sizing of the system, it was possible to simulate it in the PVsyst software, calculate the amount of energy generated by it, and understand how it met the demand of the hospital. In this part of the paper were considered losses and the efficiency of the photovoltaic system to create realistic projections of the 25 helpful life of the system.

With the necessary final value of the investment, the generation of energy through the simulation of the system, and the expenses saved with electric power, some mathematical analysis was made to verify the system's financial viability. This paper calculated the simple payback and discounted the Project the NPV (Net Present Value) and IRR (Internal Rate of Return).

With the system scaled and simulated in the PVsyst, the calculation of its necessary investment and the mathematical analyses was possible to reach the paper's conclusion, showing if the system was plausible to be implemented by UH-UFSCar or not. 


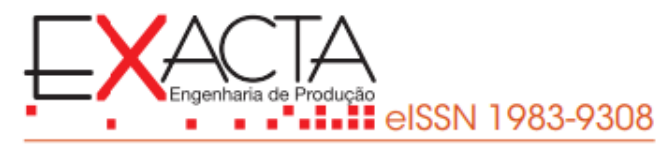

\subsection{Case Study: University Hospital of the Federal University of São Carlos - \\ UFSCar}

The Brazilian health system depends mainly on hospitals, accounting for $70 \%$ of emergency care, $27 \%$ of ambulatory care, and most hospitalizations. The sector has approximately 7,400 hospitals and 67,000 outpatient units, divided between public and private, resulting in a complex structure to coordinate, monitor, and evaluate in different scopes such as financial and organizational. Private hospitals correspond to $70 \%$ of all the beds offered, but most of the hospital care is funded by SUS through different mechanisms (Forgia and Couttolenc, 2009). In 2014 Brazil spent 9\% of GDP on health. It is essential to ensure the health sector's financial sustainability. This is not a unique challenge of Brazil, being a topic discussed today in several developed and developing countries (Coalizão Saúde, 2017; Guimarães, 2017).

University Hospitals (UHs) have a leading role in training health professionals able to address the health problems of the Brazilian population, research, development of new techniques, procedures, and therapies, as well as the incorporation of technologies developed to address these problems adequately; and, finally, guaranteeing the population's access to highcomplexity health care, which is essential to achieve complete care (Barata et al., 2010). Most UHs are under the administration of medical schools or universities, and their funding depends on the public budget for their maintenance (Medici, 2001). There are 163 teaching hospitals in Brazil, and the state of São Paulo has 37 of these hospitals (Barata et al., 2010). These teaching hospitals are essential for the state of São Paulo: in 2008, they performed $22 \%$ of the hospitalizations and consumed $38 \%$ of the financial resources of the total hospitalizations of SUS. They also performed $61 \%$ of the high-complexity hospitalizations in the state of São Paulo (Mendes and Bittar, 2010).

The hospital analyzed is the University Hospital Prof. Dr. Horácio Carlos Panepucci of the Federal University of São Carlos (UH - UFSCar), located in the city of São Carlos, São Paulo. This hospital provides care services under a public regime, developing teaching, research, and extension activities, founded in October 2014. The Brazilian Hospital Services Company administers it (EBSERH), linked to the Ministry of Education (MEC). Currently, UH has a structure of approximately 8 thousand square meters, with 54 beds, acting in the areas of Emergency Care, Adult Hospitalization Units, Pediatric, Psychosocial Care and Support Service, Diagnosis and Therapy: clinical analyzes, imaging tests (X-rays, tomography, ultrasonography) and graphic methods (electrocardiogram, electroencephalogram, and spirometry). Ferraz et al. (2018) emphasize that certain investments, such as high technology research projects, require more time to obtain returns. In hospital institutions, the financial 
Figure 1 - Local shading 1 to $10 \mathrm{~h}$

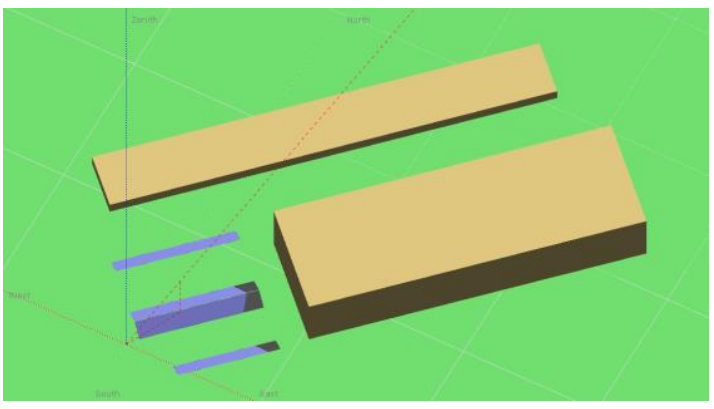

Source: Authors - PVsyst software (2018)

It was concluded by analyzing all these factors that the most appropriate place to implement the photovoltaic system is location 1. The geographical coordinates of the site are $21^{\circ} 59^{\prime} 33.1$ "S, $47^{\circ} 53^{\prime} 17.8^{\prime \prime} \mathrm{W}$. This place is a lot of cars for the hospital employees so the work is done only adds value to an area without changing or harming its current purpose. The parking lot consists of 67 parking spaces, with each parking space measuring $2.49 \times 5.0 \mathrm{~m}^{2}$, totaling $885 \mathrm{~m}^{2}$ of the area to be covered, these spaces are divided into three different covers that will be called coverage 1, 2, 3 and 4 in this paper.

Thus it is proposed that a structure be built that will serve as support for the photovoltaic system. The dimensions of this structure are $2.49 \times 6.0 \mathrm{~m}^{2}$ per vacancy, totaling $1,049.47 \mathrm{~m}^{2}$. This structure, in addition to serving as support, will also provide greater convenience for parking users.

Analyzing the different types of possible structures for the system, the structure with the best cost-benefit was the PHB Solar company, the Carport structure. By making a quotation of the Carport structure with different installation companies it was possible to obtain an average price equal to $\mathrm{R} \$ 206.85$ per structure. Given the dimensions of the structure will require 504 Carport structures totaling a total cost equal to $\mathrm{R} \$ 104,252.40$.

According to the distribution of parking spaces, 504 photovoltaic modules were needed to cover them. Among the possible models, the most interesting in terms of brand reliability, product quality, and the price was the model CS6U-330M from the manufacturer Canadian Solar Ine, as per specifications in Table 2. 
Table 2 - Specifications of solar panel

\begin{tabular}{|c|c|}
\hline Item & Painel solar \\
\hline Manufacturer & Canadian Solar Inc \\
\hline Model & CS6U-330M \\
\hline Power & $330 \mathrm{Wp}$ \\
\hline Dimensions & 1960 x 992x $40 \mathrm{~mm}$ \\
\hline Price per unit & $\mathrm{R} \$ 670.00$ \\
\hline Necessary amount & 504 \\
\hline Final cost & $\mathrm{R} \$ 337,680.00$ \\
\hline
\end{tabular}

Source: Elaborated by the authors based on the datasheet of the solar panel and the quotation with different suppliers (2018)

Headquartered in Canada, Canadian Solar is one of the largest manufacturers of photovoltaic modules in the world. One of its eight factories is located in Brazil, producing the panel CS6U-330M 1500V in the national territory. This panel has a high-quality standard, with INMETRO "A" grade certification and a 10-year warranty against manufacturing defects, and is ideal for use in networked systems such as this one. In addition, the panel has reinforced structure made of anodized aluminum with additional stabilizer bar and its photovoltaic cells are protected by a tough layer of tempered glass.

Each vacancies cover has a different number of required modules due to their different sizes. In Figure 2, each of the four covers can be observed and in Table 3 the need for modules of each cover and its inclination was raised.

Figure 2 - Parking of the UH-UFSCar divided into 4 covers

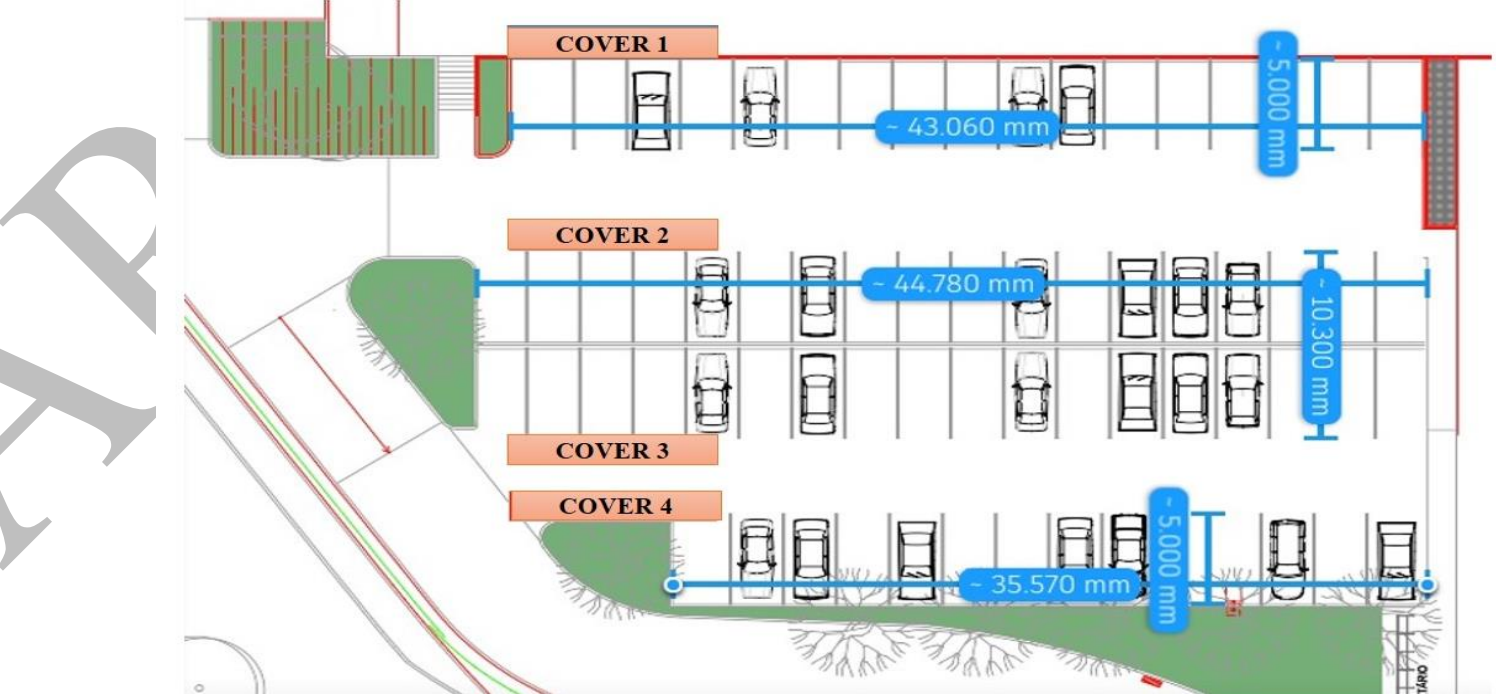

Source: Prepared by the authors (2018) 
Table 3 - Need modules coverage

\begin{tabular}{cccc}
\hline Cover & Number of modules (width) & Number of modules (length) & Inclination \\
\hline 1 & 6 & 22 & $26^{\circ}$ \\
2 & 6 & 22 & $26^{\circ}$ \\
3 & 6 & 22 & $26^{\circ}$ \\
4 & 6 & 18 & $26^{\circ}$ \\
\hline
\end{tabular}

As discussed in the literature review, to maximize the use of solar radiation, it is recommended that the panels be installed with a certain slope, which varies according to local latitude and the period of the year in which more energy is required (ANEEL, Atlas Energia Solar). With the research done on the best slope to be used in this paper, it was possible to find that a suitable slope for the installation region is equal to 26 degrees. In addition, installing the panels with a certain slope prevents the accumulation of leaves and dirt, which would remain on the panels if they were installed horizontally. The layout of the modules is as follows in the covers (Figure 3):

Figure 3 - Distribution of the modules in the four roofs

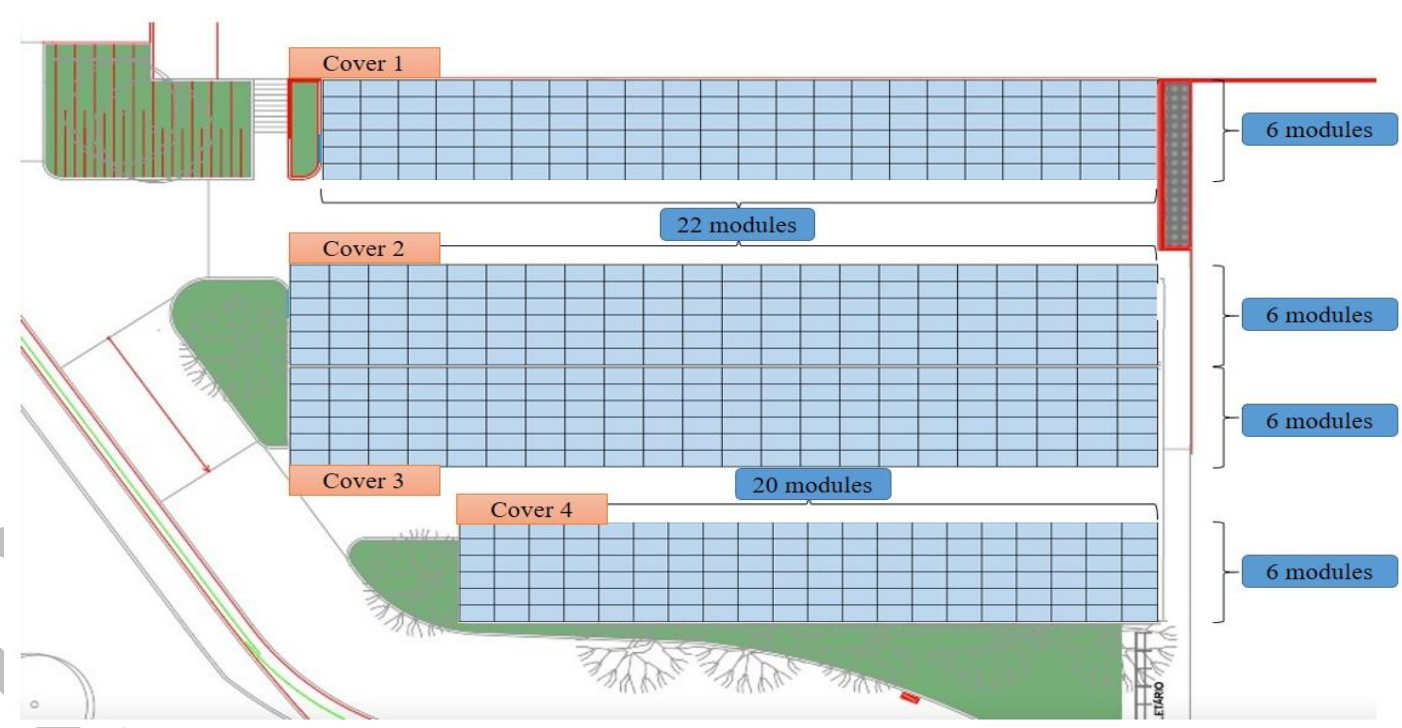

Source: Prepared by the authors (2018)

According to the designed system, it took four inverters, one for each of the covers. To choose the inverter, it was necessary to find out the sum of the power of all the panels of each cover and then choose an inverter with the approximate power, slightly smaller. Among the possible models, the most interesting one for covers 1,2 and 3 in relation to the quality, market 
recognition and price was the model CL 36.0 from the manufacturer Fronius International, according to the specifications in Table 4. For cover 4, which requires an inverter with lower power, the most suitable equipment was the ABB TRIO-27.6-TL-OUTD model (Table 4).

Table 4 - Inverter specifications of covers 1, 2, 3 and 4

\begin{tabular}{lll}
\hline Specifications & Covers $\mathbf{1 , 2}$ and 3 & Cover 4 \\
\hline Item & Inversor & Inversor \\
Manufacturer & Fronius International & ABB \\
Model & $\mathrm{CL} \mathrm{36,0}$ & TRIO-27.6-TL-OUTD \\
Power & $36 \mathrm{~kW}$ & $27.6 \mathrm{~kW}$ \\
Price per unit & $\mathrm{R} \$ 28,000.00$ & $\mathrm{R} \$ 19,000.00$ \\
Necessary amount & 3 & 1 \\
Final cost & $\mathrm{R} \$ 84,000.00$ & $\mathrm{R} \$ 19,000.00$ \\
\hline \hline
\end{tabular}

Source: Elaborated by the authors based on the datasheet of the inverter and the quotation with different suppliers (2018)

In addition to the components described above, other components are also required for the photovoltaic system to function. These components were listed, along with their average price quoted with different suppliers, in Table 5.

Table 5 - Components of the photovoltaic system

\begin{tabular}{|c|c|c|c|}
\hline Equipment & Price $(\mathbf{R} \$)$ & Quantity & Total cost $(\mathrm{R} \$)$ \\
\hline S String Box & R\$ 200.00 & 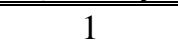 & "R\$ 200.00 \\
\hline Protection frame & $\mathrm{R} \$ 400.00$ & 1 & $\mathrm{R} \$ 400.00$ \\
\hline Black solar cable & $\mathrm{R} \$ 5.80 /$ meter & 450 meters & $\mathrm{R} \$ 2,610.00$ \\
\hline Red Solar Cable & $\mathrm{R} \$ 5.80 /$ meter & 450 meters & $\mathrm{R} \$ 2,610.00$ \\
\hline VD/AM solar cable & $\mathrm{R} \$ 5.80 /$ meter & 450 meters & $\mathrm{R} \$ 2,610.00$ \\
\hline
\end{tabular}

Source: Elaborated by the authors based on the quotation with different suppliers (2018)

For the installation of the system was listed different companies that would do the service in São Carlos. At these prices, the average value obtained was $\mathrm{R} \$ 130.000,00$. It is important to consider that the system will need to be maintained and therefore a maintenance cost equal to $0.5 \%$ of the project cost per year (Elysia, 2017), totaling R \$ 85,420.30.

With the costs of materials and installation of the photovoltaic system raised, it was possible to calculate your investment required. This investment is equal to approximately $\mathrm{R} \$ 768,782.70$

Through the insertion of some data in the software used for the simulation of the system studied in this paper, PVsyst, it was possible to find the energy generated per month by the 
installed photovoltaic system. Some of the data considered were: number and type of panels and inverters used, the solar incidence of the installation region, nominal power and shading to which the system was subjected. After insertion of these data, PVsyst estimated that the system would generate 194.2 MWh/year in the first year from the installation.

In the graph of Figure 4, it is possible to observe the energy produced by the system in the first year of operation per month. It is possible to check, in blue, the losses that happen before the conversion of energy in the form of radiation to electric energy. In gray, it is possible to verify the electrical losses of the system itself and in orange, it is the energy actually injected into the network.

Figure 4 - Simulation of energy production in the first year of operation

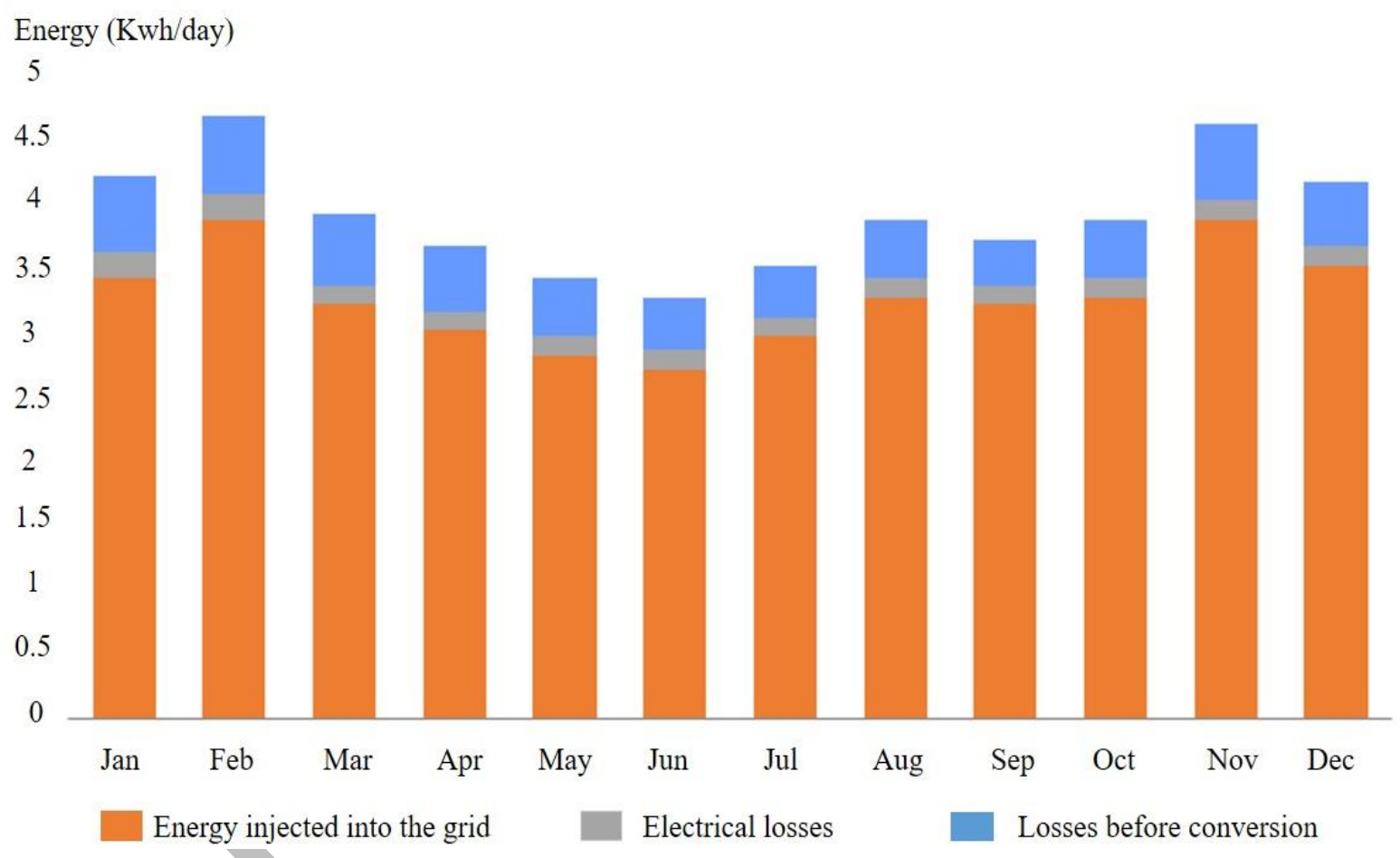

Source: Elaborated by the authors based on data obtained through the simulation of the photovoltaic system in PVsyst software (2018)

System components lose efficiency with increasing temperature. Thus, in colder periods it is possible to observe that the efficiency of the system is above $83 \%$, while in hotter periods this efficiency is closer to $80 \%$.

The energy generated with the system loss diagram system in the first year of operation equals 194.2 MWh, which results in approximately 25\% of the current energy consumption of the HU-UFSCar. As the efficiency of the system decays over time, a reduction of $0.5 \%$ per year, the default value of the PVsyst, was considered. 
Figure 5 shows a projection of HU-UFSCar's electricity consumption in the coming years. In orange, it is possible to observe the generation projection of the system for the next 25 years, with the decay of appropriate production. In gray, it is possible to observe the part of the consumption that is acquired of the network since the generation of the photovoltaic system is limited.

Figure 5 - Projection of electric energy consumption by HU-UFSCar

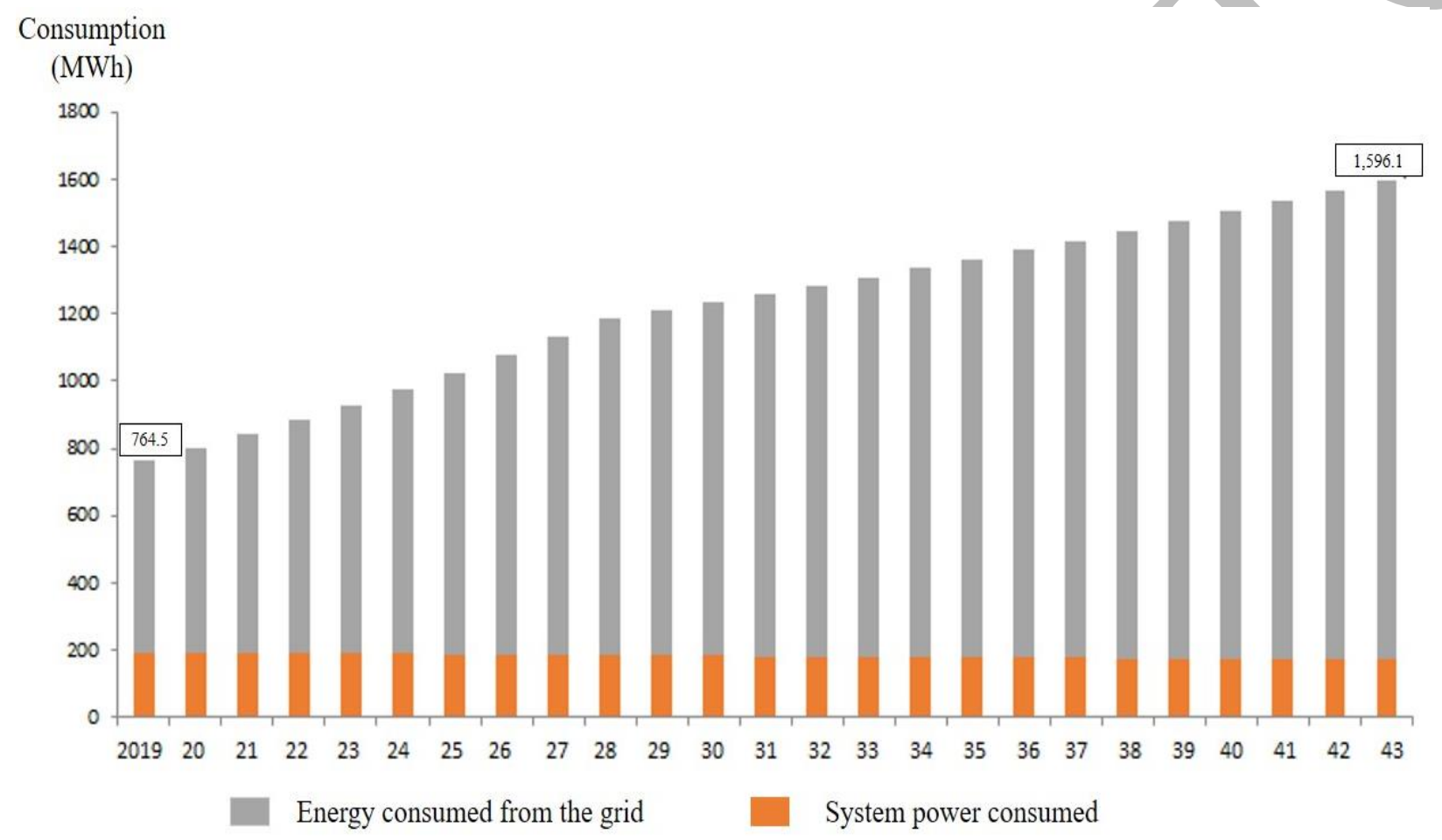

Source: Prepared by the authors (2018)

For the first 10 years of the system's life, it was considered an increase in the consumption of electric energy of the hospital equal to $5 \%$ per year, since hospital consumption is not yet mature. For the subsequent 15 years, growth of $2 \%$ per year was considered.

In addition to the growth in the consumption of existing capacity, there is also an increase in the hospital's installed load for the coming years due to the completion of the surgical center's work. The entry of this new load will not impact the present project since the consumption for which this project is being scaled will continue to exist. In addition, there is no information on the consumption pattern of this new load.

The photovoltaic system only works with the presence of light, in this way, this paper considers that the proposed system only supplies the consumption of the off-peak time. It is important to consider that electric energy tariffs are subject to periodic readjustments and, 


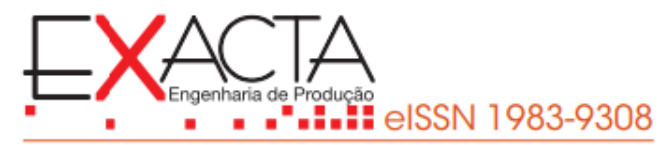

therefore, an increase of $10.17 \%$ per year $(\mathrm{G} 1,2018)$ was considered in the hour-end tariff, growth referring to the Southeast tariff.

From the projections of energy generated by the system and the electric energy tariff, if this energy was consumed from the grid instead of the consumption generated by the system and the tariff that would be paid for the energy, if it were consumed from the grid, instead of the system photovoltaic, it is possible to calculate what would be the financial savings from the existence of the photovoltaic system.

The total investment required for the project is equal to $\mathrm{R} \$ 768,827.70$. To analyze whether this investment is worth it is important to analyze the three methods: NPV, IRR, and Payback - Simple and Discounted.

This paper requires an investment of $\mathrm{R} \$ 768,782.70$ and has a return of $\mathrm{R} \$ 3,557,265.12$ over the 25 years, with a positive result equal to $\mathrm{R} \$ 2,788,482.42$. As the project has positive NPV (NPV>0) the project is considered financially viable. Therefore, it is verified that the project to install the photovoltaic system in the UH-UFSCar proved to be feasible. Therefore, it is recommended that the investment be executed through the NPV.

Taking into consideration the necessary investment of the photovoltaic system and the returns generated over time, it was possible to calculate the IRR of this paper, obtaining a value of $21.53 \%$. Thus, from the IRR method, the present paper shows an interesting way of UHUFSCar investing its money.

It is important to note that the investment in the two scenarios has a certain difference, since if applied in savings, it has the possibility of redemption in any period over the 25 years, while if applied in the photovoltaic system, there is no possibility of redemption. However, even without the possibility of redemption, investment in the photovoltaic system is more attractive than investing in savings.

The simple payback, number of periods necessary for the cash flow to equal all invested capital (Rebelatto, 2004), of the present paper was calculated and is equal to 7 years. That is, the exact period of recovery of the investment from the cash inflows is equal to 85 months. The discounted payback, taking into account inflation in the period, is equal to 8.4 years, that is, 101 months.

To analyze if these values make sense according to the expectation of the paper, other investments in photovoltaic systems were analyzed and it was possible to observe that the payback of projects in Brazil is usually up to 8 years, as reported by the Brazilian Association of Solar Photovoltaic Energy (ABSOLAR, 2018). Both simple and discounted payback is in line with the Brazilian average and, therefore, show interesting results. 
Another important factor to consider when analyzing payback is the lifetime of the system since a project should only be accepted by this method if the payback time is less than the time relative to the project life. In this case, the payback is approximately one-third of the system's useful life, which is also interesting. Given that the payback of the present paper is in agreement with the average paybacks of photovoltaic systems in Brazil and is considerably smaller than the useful life of the project, it was possible to conclude that this project is feasible according to the payback method.

As discussed in the literature review, it is unwise to consider this method only as an investment decision because it does not include cash flows after the recovery period. The payback method can lead to the choice of a project that has a very low return period, disregarding a project with a longer period, but which can generate greater wealth for the investor, that is, that has a higher NPV. If a given investment has a higher annual flow compared to another investment, this will imply a shorter recovery period, but it can only be an illusory payback if, after this period, the investment presents negative or very low flows, for example. To avoid such risks, the payback method was not the only method of decision when analyzing the financial viability of the UH-UFSCar photovoltaic system.

\section{Concluding remarks}

From all the study done for the elaboration of this paper, it was possible to verify the relevance of distributed generation in the current national scenario. Brazil has some privileged physical characteristics for the implementation of this type of system, as its high index of average insolation.

Using a photovoltaic system, a clean source of energy, brings different benefits such as less dependence on the transmission and distribution systems of electric energy, low environmental impact, reduction in the charging of electricity networks, minimization of losses, diversification of the energy matrix and decrease of the user's expenses with electric energy, something very relevant for some consumers. Institutions such as hospitals have a high consumption of electric energy, due to a large number of electrical and electronic equipment used for patient care, so the use of photovoltaic technology in hospitals is an interesting topic, as it can lead to a decrease in their operating costs, in addition to the other benefits already mentioned above. In this way, the UH-UFSCar, in the city of São Carlos, was chosen for the development and analysis of the photovoltaic system proposed. The proposed system would be implemented in the hospital parking lot, allowing the chosen area to continue with its original 
purpose and still add greater convenience to parking users due to the shadow caused by the structure implemented to support the photovoltaic system.

By dimensioning, by simulating the proposed photovoltaic system, it was possible to conclude that it will supply approximately $25 \%$ of the total energy consumption of UH-UFSCar in its first year of operation. This rate is not constant, since both the hospital consumption has an expected growth, since the hospital is not yet in a mature phase of use, as the productivity of the photovoltaic system drops by $0.5 \%$ each year of use.

From the sizing and simulation of the results of the system, it was possible to do some financial analysis to verify the feasibility of the proposed system.

Initially, the payback was calculated, the number of periods necessary for the cash flow to equal all invested capital and the simple payback is equal to 7 years. That is, the exact period of recovery of the investment from the cash inflows is equal to 85 months. In order to analyze if this value makes sense, other investments in photovoltaic systems were analyzed and it was possible to observe that the system's payback in Brazil is usually up to eight years. In addition, a project should only be accepted by this method if the payback time is less than the project lifetime, and in this case, the payback is less than one-third of the system's lifetime. In this way, according to the payback method, the investment is viable and attractive.

To verify the viability, the Internal Rate of Return of the proposed system was also analyzed and compared with the return of another possible investment that the UH-UFSCar could do, ie, the Minimum Attractiveness Rate. Given that the hospital is not an institution that practices investments, the Minimum Attractiveness Rate considered was the savings income, equal to $4.53 \%$ per year. The IRR of this paper is equal to $21.53 \%$ and, therefore, the investment is very interesting according to this analysis, because the rate of return is considerably higher than the Minimum Attractiveness Rate. Finally, the NPV of the work was analyzed and it is equal to $\mathrm{R} \$ 2,788,482.42$. Since a project is feasible if its NPV was greater than zero, this work is feasible according to this analysis.

Thus, given that the proposed investment proves feasible and interesting according to all the financial analyzes made, it can be concluded that this paper is financially attractive to UH-UFSCar. In addition, considering qualitative factors such as the adoption of a clean source of energy, this work is also attractive for the hospital. It is important to emphasize that the value of this paper is not in the actual money generation, but in the savings, it will provide to the hospital since the institution's consumption of electricity will be reduced. 
Nowicki, M. (2008). Introduction to the Financial Management of Healthcare Organizations. (4.ed.) Washington: Alpha.

Pergher, A. N. Q. (2011). Pequena central hidrelétrica: procedimentos práticos para suaimplantação utilizando instrumentos públicos (Doctoral dissertation, Universidade de São Paulo).

Pinho, JT, Galdino, MA. Manual de Engenharia para Sistemas Fotovoltaicos: CEPEL - CRESESB. Rio de Janeiro, 2014. 530 p. Electronic material. Retrieved on Apr 10, 2018, in http://www.cresesb.cepel.br/publicacoes/download/Manual_de_Engenharia_FV_2014.pdf

Rebelatto, DAN. (2004). Projeto de investimento: Com estudo de caso completo na área de serviços (1 ed). Barueri/SP: Editora Manole Ltda.

Rehman, E., Ikram, M., Feng, M. T., and Rehman, S. (2020). Sectoral-based CO 2 emissions of Pakistan: A novel Grey Relation Analysis (GRA) approach. Environmental Science and Pollution Research, 27, 29118-29129.

REN21. (2020). REN21 - Building the sustainable energy future with renewable energy.

Rocha, ACG. (2012). Eficientização Energética em Prédios Públicos: Um Desafio aos Gestores Municipais Frente aos Requisitos de Governança e Sustentabilidade. Retrieved on Nov 20, 2018, in https://bibliotecadigital.fgv.br/dspace/bitstream/handle/10438/10262/Trabalho\%20Individual\%20FGV $\% 20-\% 2027.11 .2012 \% 20-\% 20$ Vers\%C3\%A3o\%20final.pdf

Sauaia, RL. (2017). Energia Solar Fotovoltaica: Panorama, Oportunidades e Desafios: Brasília: Absolar - Associação Brasileira de Energia Solar Fotovoltaica.

Sidawi, J., Abboud, N., Jelian, G., Habchi, R., Eltahchi, M., \& Salame, C. (2011). Photovoltaic solar modules electrical properties evolution under extreme stress. In 1st Franco-Syrian Conference on Renewable Energies, Damask (pp. 24-28).

Tsalis, T. A., Malamateniou, K. E., Koulouriotis, D., and Nikolaou, I. E. (2020). New challenges for corporate sustainability reporting: United Nations' 2030 Agenda for sustainable development and the sustainable development goals. Corporate Social Responsibility and Environmental Management, 27(4), 1617-1629.

UFSCar - Universidade Federal de São Carlos. Hospital Universitário. Electronic material. Retrieved on May 28, 2018, in https://www2.ufscar.br/visitante/hospital-universitario

United Nations. Sustainable Development Goals: 17 Goals to Transform Our World. 2015. Electronic material. Retrieved on Apr 08, 2018, in https://www.un.org/sustainabledevelopment/

Vidyarthi, H., and Mishra, R. K. (2020). Dynamics among banking penetration, transport infrastructure, and regional growth: An empirical note from Indian states. International Journal of Economic Policy in Emerging Economies, 13(1), 1-12. https://doi.org/10.1504/IJEPEE.2020.106680

Villalva, MG. (2015). Energia Solar Fotovoltaica: Conceitos e Aplicações (2.ed) São Paulo: Érica.

Xia, C., and Wang, Z. (2020). The effect of fossil fuel and hydropower on carbon dioxide emissions: EKC validation with structural breaks. Journal of Environmental Engineering and Landscape Management, 28(1), 36-47. https://doi.org/10.3846/jeelm.2020.11832

$\mathrm{Xu}$, G., Schwarz, P., and Yang, H. (2020). Adjusting energy consumption structure to achieve China's CO2 emissions peak. Renewable and Sustainable Energy Reviews, 122. 


\section{Appendix A - PVsyst Report}

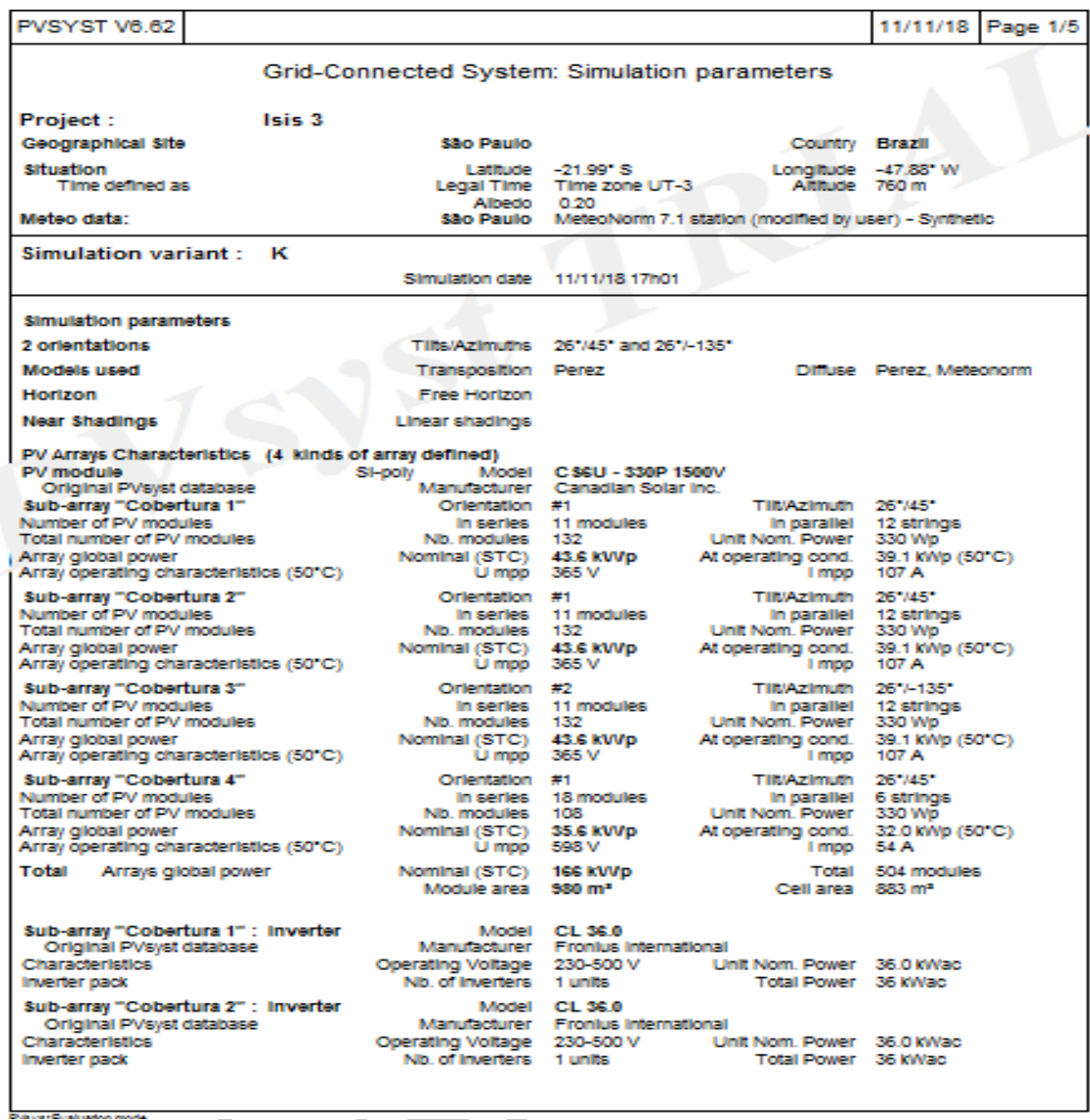

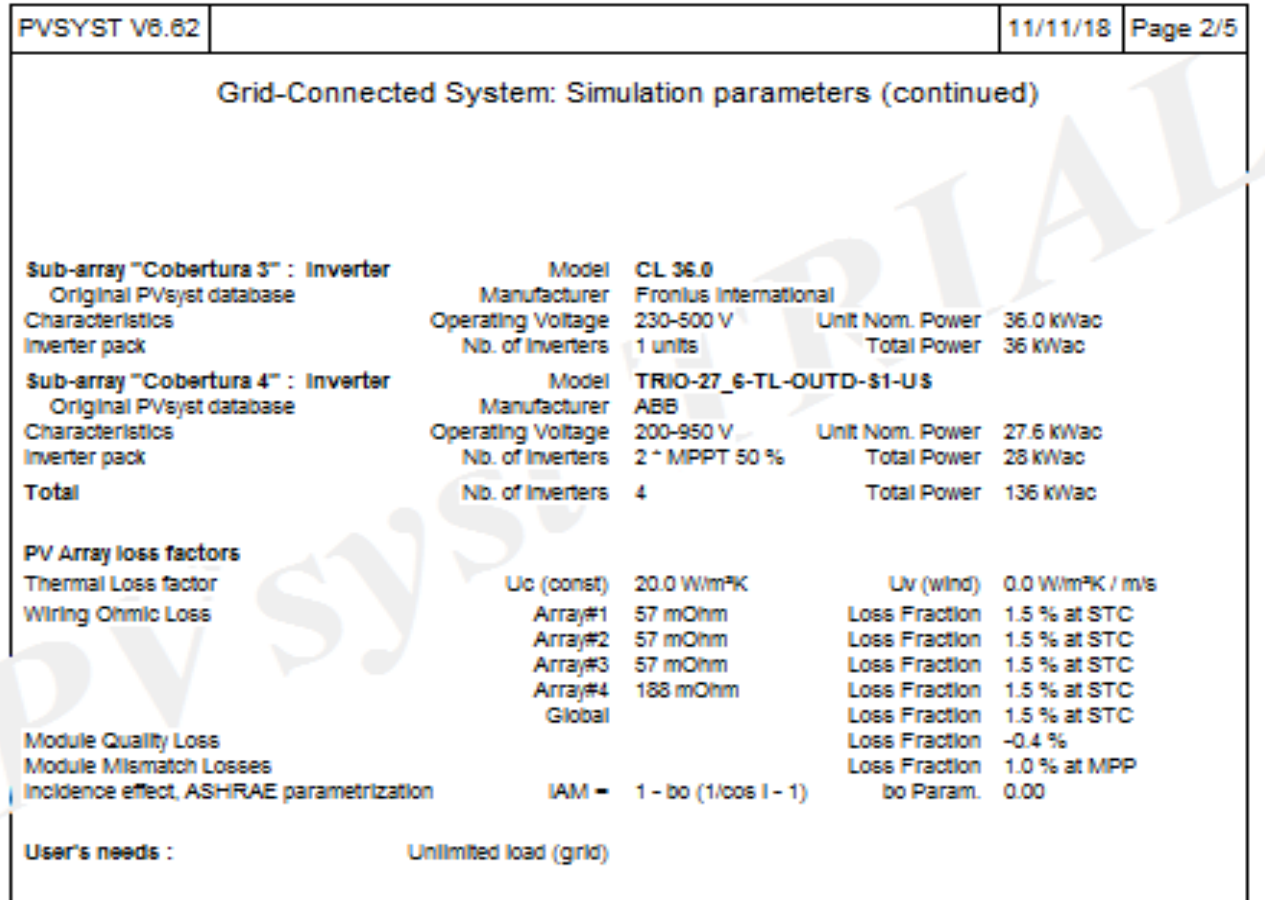




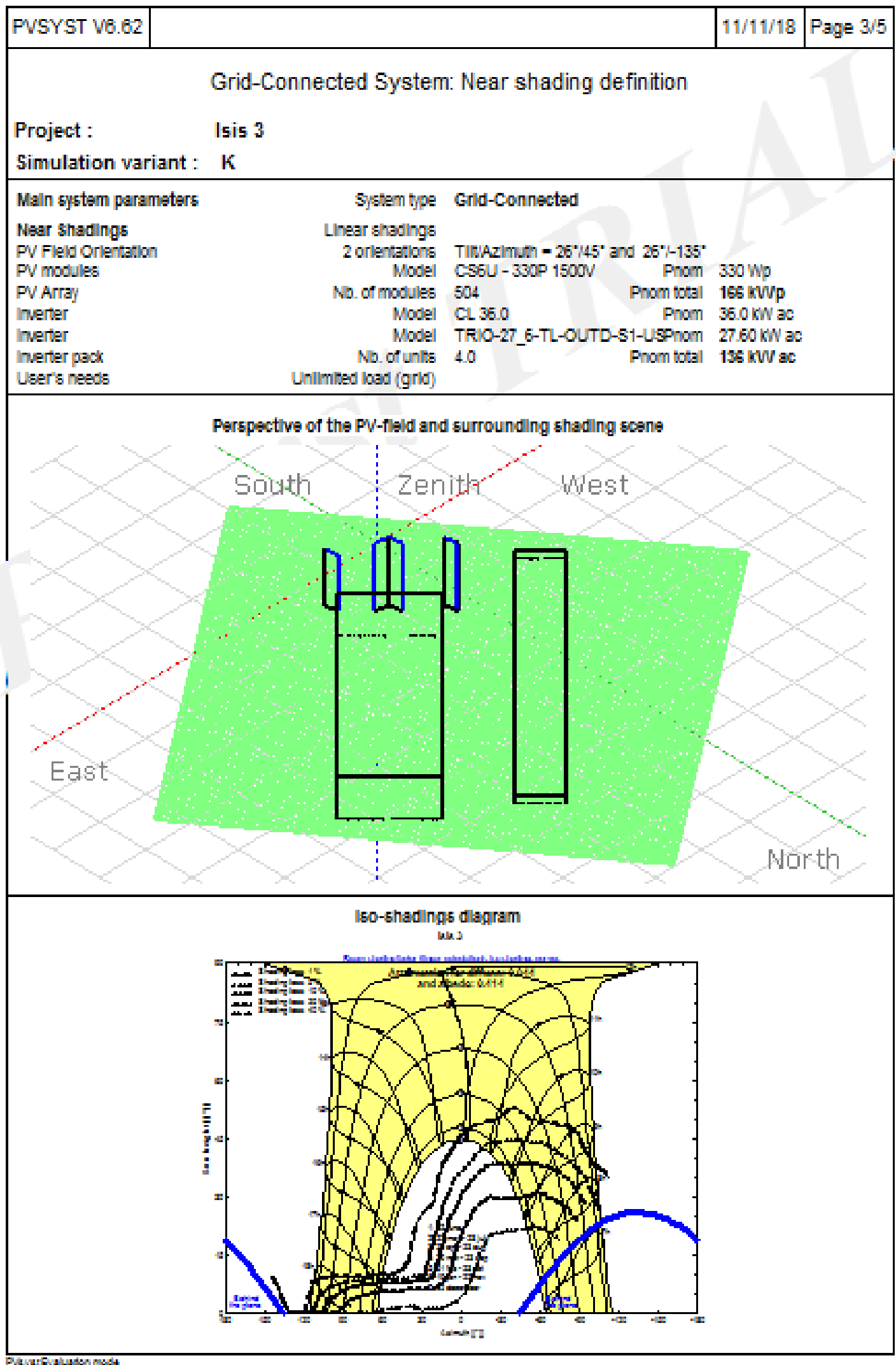

